since the second World War.

The Joint Committee is in trouble for other reasons, too. Next month, when Democratic members of the House meet to discuss the political agenda there, two nuclear critics, Clarence Long of Maryland and Jonathan Bingham of New York, will propose that the committee be scrapped and that some of its functions be transferred to the House Science and Technology Committee, among others. Thus, the Joint Committee is under combined attack in both the House and the Senate, and its chances of surviving are generally considered to be less than even. One point going against the committee is that five of its nine members, including the chairman, Senator John Pastore of Rhode Island, either retire at the end of this year or were defeated at the polls. Moreover, two of the most powerful members of the Joint Committee, Senator Jackson and Representative Mike McCormack, would stand to inherit some of its authority in their own committees, so they probably wouldn't be too sorry to see the Joint Committee disappear. It should be noted that the Joint Committee has been consistently pro-nuclear, and its demise would be welcomed by anti-nuclear critics.

- Another major Senate change proposed by the select committee is the creation of a new committee on Environment and Public Works, founded mostly on the present Public Works Committee headed by Senator Jennings Randolph. It would be responsible for environmental programmes together with nuclear regulation, which would mean that responsibilities for developing and regulating nuclear power would be divided between separate committees.

The proposed reforms are expected to be one of the first items of business when the Senate reconvenes early in January, but negotiations are already under way behind the scenes, as Senators who stand to lose some of their jurisdiction are striving to hang on to their authority.

It is quite possible that the opposition will be too strong and that the proposals will be quietly killed off or severely watered down by consigning them to the Rules Committee for further study. But at least the proponents of the reforms are preparing to put up a spirited fight. Senator Adlai Stevenson, the chairman of the select committee, is said to be threatening to introduce a resolution blocking the appointment of new senators to committees and the appointment of new committee chairmen if his proposals are simply shunted aside. Such a resolution could tie up the business of the Senate for a long time if it were approved. A more likely development is that differences will be settled by behind-the-scenes negotiations in the next few weeks, and a compromise reform plan will be worked out in conjunction with the Rules Committee.

\title{
Genetic manipulation: enter the environmentalists
}

LAWYERS for two environmental organisations have filed a formal petition with the Department of Health, Education and Welfare (HEW) requesting extensive public hearings and the development of legally binding regulations to control all recombinant DNA experiments in the United States. It is the first time that environmentalist groups have formally entered the swirling dispute over the risks and benefits associated with recombinant DNA, and the petition is probably only the opening shot in what could develop into a lengthy legal fight.

Filed by the Environmental Defense Fund and the Natural Resources Defense Council, the petition has been endorsed by Robert L. Sinsheimer, chairman of the Division of Biology at California Institute of Technology. Sinsheimer, a leading critic of recently-issued safety guidelines governing recombinant DNA research supported by the National Institutes of Health (NIH), sent a letter to HEW along with the petition.

The petition requests two actions by HEW. First, public hearings should be held to allow interested parties to state their case and to have their views taken into account; and then HEW should develop binding regulations to control all recombinant DNA experiments in the United States. In the meantime, the petition asks HEW to extend the voluntary NIH guidelines to cover experiments supported by other agencies and by non-government bodies.

The petition is clearly motivated by the belief that the NIH guidelines are inadequate to control the potential hazards associated with recombinant DNA research. It states that the guidelines "are the product of the deliberations of scientists who are now conducting recombinant DNA research", and argues that "little discussion was devoted to whether or not these experiments ought to be performed at all, even though the question was raised both by concerned laymen and by prominent scientists".

The petition also points out that the chief drawback in the guidelines is that they formally apply only to research supported by NIH, leaving industrial research essentially unregulated. Moreover, there is no requirement for federal monitoring to ensure that the guidelines are being followed. Those drawbacks are also bothering some state and local officials, in New York State for example.

The petition will probably be turned down on the grounds that HEW lacks authority to tell other agencies or private industry what to do, but the environmental groups are likely to press their case either in the courts or on Capitol Hill. Senator Edward Kennedy has already said that he may consider introducing legislation to make the NIH guidelines binding on everybody who wants to conduct recombinant DNA studies.

Meanwhile, an inter-agency task force has been established in Washington to discuss ways in which the NIH guidelines can be extended to other federal agencies. According to one official concerned with the task force, it will also discuss the possibility of establishing a monitoring procedure to ensure that the guidelines are followed, and it will also look into what industry is doing and whether the federal government could (or should) regulate industrial recombinant DNA experiments. One possible outcome of the task force's deliberations is that the NIH guidelines may be made into legally binding regulations covering all agencies and industry as well. If so, that would accomplish some of the petition's demands.

The task force is headed by Dr Fredrickson, and consists of representatives of other federal agencies. It meets in private since it does not fall under the terms of the advisory committee act, and it is expected to come up with some recommendations by mid-January.

If it does recommend the adoption of legally binding regulations and a monitoring procedure, a key question would be which agency should take responsibility for enforcing them. NIH officials are anxious not to be placed in the position of both supporting and regulating the research, and the task may therefore fall to a regulatory agency such as the Occupational Safety and Health Administration. 